\title{
New Needed Quality Management Skills for Quality Managers 4.0
}

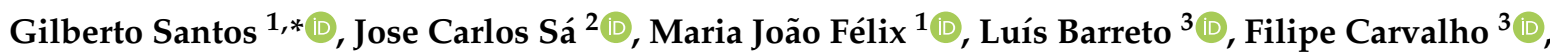

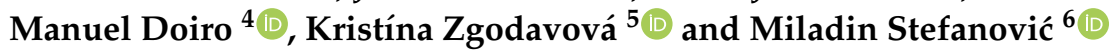

1 ESD-Design School-Polytechnic Institute Cavado Ave, 4750-299 Barcelos, Portugal; mfelix@ipca.pt

2 Engineering School, Polytechnic of Porto, 4200-465 Porto, Portugal; cvs@isep.ipp.pt

3 Escola Superior de Ciências Empresariais-Instituto Politécnico de Viana do Castelo, 4930-600 Valença, Portugal; lbarreto@esce.ipvc.pt (L.B.); filipecarvalho@esce.ipvc.pt (F.C.)

4 Industrial Engineering School/IEA, Vigo University, 36208 Vigo, Spain; mdoiro@uvigo.es

5 Faculty of Materials, Metallurgy and Recycling, Technical University of Košice, 04001 Košice, Slovakia; kristina.zgodavova@gmail.com

6 Center for Quality, Faculty of Engineering, University of Kragujevac, 34000 Kragujevac, Serbia; miladin@kg.ac.rs

* Correspondence: gsantos@ipca.pt

Citation: Santos, G.; Sá, J.C.; Félix, M.J.; Barreto, L.; Carvalho, F.; Doiro, M.; Zgodavová, K.; Stefanović, M. New Needed Quality Management Skills for Quality Managers 4.0. Sustainability 2021, 13, 6149. https:// doi.org/10.3390/su13116149

Academic Editor: Hefin Rowlands

Received: 24 April 2021

Accepted: 25 May 2021

Published: 30 May 2021

Publisher's Note: MDPI stays neutral with regard to jurisdictional claims in published maps and institutional affiliations.

Copyright: (C) 2021 by the authors. Licensee MDPI, Basel, Switzerland. This article is an open access article distributed under the terms and conditions of the Creative Commons Attribution (CC BY) license (https:/ / creativecommons.org/licenses/by/ $4.0 /)$.

\begin{abstract}
Digitalization is rushing throughout the world, namely, in industrial and societal infrastructures. Hence, digital transformation becomes a pillar of industrial policy, known in Europe as "Industry 4.0," in China as "made in China 2025," in Asia as "Smart Cities," in Japan as "Society 5.0," and in North America as "Industrial Internet." These transformations will change the industrial landscape, toward Quality 4.0 and therefore, our lives. The presented research was conducted on quality management employees in Portugal and it aims to analyze if such employees have the perception of the impact of Industry 4.0 in the quality management profession and the required and needed skills. After analyzing the answered questionnaires, 90 results were considered valid. This is the sample of our study. Simultaneously, the goal of this research is also to review and analyze the main topics in progress related to quality management for the fourth industrial revolution and how quality emerges of this change. The professionals that work on quality management must have creative thinking, be leaders, know how to communicate and work as a team, as well as, to have knowledge and understanding of ICT (Information and Communications Technology), and main pillars of Industry 4.0. These are the main findings. Besides that, they must know how to motivate their work teams, be open to change, know how to use Big Data to make decisions and above all, they must know how to manage conflicts. In addition, quality professionals must promote the design and production of first class products, be the defenders of their customers within the organization, and finally, they must create value for the stakeholders.
\end{abstract}

Keywords: quality management skills; digitalization; industry 4.0; quality 4.0; sustainability

\section{Introduction}

The fourth industrial revolution, also called Industry 4.0 [1] is now a reality and is propelling major changes in industries, with machines redefining and adapting themselves. Quality 4.0 is a reference to Industry 4.0. Consequently, new quality-management skills are needed for Quality 4.0 managers [2]. According to Dan Jacob [3] and other authors, Quality 4.0 connects new technologies with traditional quality methods to achieve new optimums in performance, operational excellence, and innovation. The fourth Industrial Revolution is changing business models, firms' strategies, enterprise organization, value and supply chains, products, and as such, production processes, skills [4-6] and it presents significant challenges to manufacturing companies from the organizational, technological, economic, social, and management points of view [7-9], where Made-in-China 2025 [10] also appears in this challenge of change. Hence, this new industrial paradigm also comes with new standards and promotes the redefinition of current jobs [11] and the consequent 
skills $[12,13]$ including changes in society [14], as it is also a response to the nowadays challenges emerging in fast-changing environments. According to Aldag and Eker [15], Quality 4.0 combines new technologies with common quality methods and tools, to achieve new optimums in performance, operational excellence, and also, in innovation. The new technologies include, among others, Big Data, cloud computing, machine learning, artificial intelligence, IoT-connected operations with devices. Moreover, new forms of collaboration and traceability, such as, block chain, are very important in this period, especially when factors affecting competitiveness can vary. Such quality systems lead companies to perform better, to greater operational excellence, and consequently, to process innovation. Realtime control of machines, APP-driven process control, Big Data, real-time scorecards, cloud computing, artificial intelligence, block chain, and new apps, such as, Augmented Reality (AR)/Virtual Reality (VR) provide new forms of collaboration among all parts of a production cycle and, also, in a supply chain $[16,17]$. The factory of the future is characterized by smart and interconnected real-time functions, processes, and services [18]. Hence, the workplace is in a fast process of change and business leaders need to solve the challenges that the near future will bring to enterprises [12]. Does this mean the need for changes regarding the quality profession and the quality professionals' skills? The use of new technologies and the redefinition of industrial processes are fundamental to claim the use of Industry 4.0. However, people are also an important factor to guarantee the success of this industrial revolution. Thus, employees in all areas, but especially in the quality area, must have the appropriate competencies and skills. The Industry 4.0 trend is here to stay and to change the way we work and live, posing challenges to companies and employees. According to Lages [19], similar to animal life and plant species, enterprises and human society also must adapt to new challenges, or they can disappear. This adaptation process implies solving hard problems, overcoming possible crises, and addressing constant changes. Although quality management system became popular in the last 1980s and 1990s, the 21st-century companies in the era of Industry 4.0 are improving, considerably, that concept. So, some important questions arise: (1) How will the quality certifications be in the future? Will quality management take on a new meaning regarding Industry 4.0? What kind of skills are needed by quality managers to prepare their organizations for the so-called Industry 4.0?

Having that into consideration, the present research, conducted on quality management employees, aims to analyze if such employees have the perception of the impact of Industry 4.0 in the quality management profession and the required skills. Simultaneously, the goal of this research is also to review and analyze the main topics in progress related to quality management for the fourth industrial revolution and how quality can emerge of this change.

\section{Literature Review}

The Fourth Industrial Revolution, also known as Industry 4.0 integrating Quality 4.0, is a "mental model" for understanding and influencing how society and emerging technologies are changing, how value is created, exchanged, and distributed across economic and social systems. Industry 4.0, which started off as a brainchild of Germany, is being adopted by countries around the world [20], where the "real" and the "virtual" world are to be seamlessly connected, giving rise to what are known as cyber-physical production systems. Thus, traditional manufacturing processes are undergoing an enormous transformation where new technologies will be included such as, among others, artificial intelligence, machine learning, intelligent process automation, connected devices, and operations, 5G technology, new forms of collaboration, Big Data analytics, cloud computing, cybersecurity, social media, and block chain.

These are all related to the transformation of production processes caused, simultaneously, by the use of existing technologies and the new ones, which work together leading to new opportunities for enterprises [21], as well as, challenges. Such technologies include: Internet of Things (IoT), Machine Learning, Artificial Intelligence, Data Mining, 
and Cyber-Physical Systems (CPS) [22,23]. In Industry 4.0, repetitive work will not be executed by workers, but by robots or advanced multi-function manufacturing machines. People will be more focused on integrating, managing, and controlling those machines' work and tasks, and will also need to analyze large amounts of data, using the newest and smartest available technologies, but new educational approaches and competences will be needed [24]. These features will propel the introduction of the Quality 4.0 concept $[2,3,25,26]$ that, and as a reference to the Industry 4.0 , can be considered as the use of new artificial intelligence technologies, and other technologies from Industry 4.0 toolbox, together with traditional quality management methods. Quality 4.0 leads us to the digitalization of Total Quality Management and its impact on quality technology, production processes, and people that work. It builds upon common quality tools and also considers, automation and artificial intelligence for improving performance. After this, it is necessary making timely data-driven decisions of various scenario, involving all the possible stakeholders and providing transparency, visibility, and connectedness [27]. As everything will be smart in the near future, we will see a disruptive impact on manufacturing companies, that is, a new paradigm will emerge. Industry 4.0 is the new challenge and, at the same time, we will see the tipping point for the decline of conventional applications [28].

The Fourth Industrial Revolution is enabled by the digital technologies of the third one, and is represented by breakthroughs in fields as diverse as: advanced robotics and drones; artificial intelligence and machine learning; biotechnologies and precision medicine; virtual, augmented and mixed reality systems; new approaches to energy generation storage; multidimensional printing; new materials, etc. These, and others to come, are combined in ways that will once again transform how human beings communicate, produce things, transport people and goods, and interact [29]. As regards to our digital presence, by $2025,80 \%$ of people across the world will have a digital presence, according to $84 \%$ of 800 technologies executives surveyed [30]. Hence, Industry 4.0 leads to the digitalization era. Everything is digital: production systems, business models, environments, operators, machines, products and services. It is all interconnected inside the digital scene with the corresponding virtual representation. The physical flows will be mapped on digital platforms in a continuous and seamless manner [28]. Thus, the modern industry requires the intelligent development of the product throughout its entire life cycle, from concept to recycling. These intelligent/smart products have information about their production processes, quality management, future application, and recycling. The referred products support active manufacturing processes (when will be produced, with what parameters, with what materials should be produced, when, what kind of modifications, etc.). Under these conditions, the management of quality has to meet new requirements imposed by the fourth industrial revolution [31]. Hence, quality teams must take an active leadership role in these initiatives because while Quality 4.0 is fueled by technology, the true transformation occurs in culture of quality, leadership, and quality processes. Success with Quality 4.0 requires a solid traditional quality foundation. Quality 4.0 does not replace traditional quality methods, but according to [3], rather builds and improves upon them. Blass and Hackston [12] claim that future skills are encompassed by 52 skills and personal attributes, 43 work-related abilities, and 43 subjects and knowledge bases. With regard to personal skills and attributes, the most important in the next 10 years, agreed by the surveyed respondents, would be: the ability to empower others; ability to learn; commitment to lifelong learning; creativity (generation of ideas); flexibility (willingness to change); foresightedness (ability to predict future occurrences); holistic thinking abilities (ability to see the whole situation and its consequences); taking initiatives (ability to start things themselves); integrative thinking abilities (thinking outside of functional areas); visionary (knowing where you are going). According to Gunasekaran and Subramanian [32], the main aspects related to human aspects in quality in the era of Industry 4.0 are: capturing message credibility and supplier involvement aspects in qualify function deployment; leadership emphasis and process flexibility in achieving economic sustainability; business models and tactics for peer involvement of employees within enterprises; business mod- 
els that study quality management influence in a multi-cultural environment. The same authors state that the main technological aspects of quality in the era of Industry 4.0 are: role of technology, automation, and IT/IS in quality management and its relationship with employee empowerment. Other authors such as Araújo et al. [33] Bravi et al. [34] Santos et al. [35], Sá et al. [36] state that increasing customer forecast, demanding, global competition, and the continuous complexity of products are very important reasons why quality management has become indispensable in nowadays companies and quality of process and product [37], became an integral part of corporate strategies and policies [38]. Hence, the notion of employee empowerment is a core principle of quality and organizations need to identify the core competencies required for the next step of quality. The opportunity to delight and wow customers will be, certainly, a very important source of competitive advantage [39].

According to the WEF (World Economic Forum) [40], key skills demand trends include, on the one hand, a continued fall in demand for manual skills and physical abilities and, on the other hand, a decrease in demand for skills related to the management of financial and other resources, as well as, basic technology installation and maintenance skills (Figure 1). Skills continuing to grow in prominence by 2022 include two important topics, such as, "Analytical thinking and innovation" as well as "Active learning and learning strategies." The sharply increased importance of skills, such as technology design and programming highlights the growing demand for various forms of technology competencies identified by employers surveyed for this report [40]. Proficiency in new technologies is only one part of the 2022 skills equation, however, as "human" skills such as "creativity, originality, and initiative," "critical thinking," persuasion, and negotiation will likewise retain or increase their value, as will attention to detail, resilience, flexibility, and "complex problem-solving." "Leadership and social influence" as well as "emotional intelligence" and service orientation, also will see an outsized increase in demand relative to their current prominence [40].

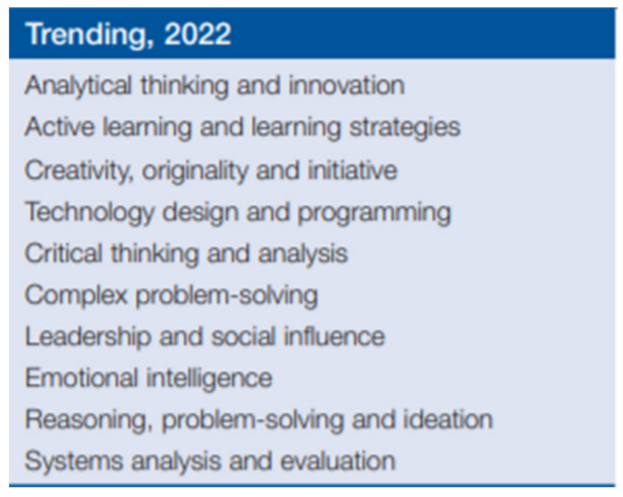

Figure 1. Trending skills demand to 2022 [40].

In a general way, trending skills demand to 2022 such as presented in Figure 1 [40], are necessary. With the arrival of the Industry 4.0 paradigm, companies will face not only challenges in finding the skilled employees, but also other challenges related to their existing workforce, that must be adapted and helped with skill development programs [20] namely: (1) up-skilling: companies will have to up-skill their workforce via in-house or external training centers. For example, an assembly line, or production worker involved in manually fitting a part will be required to operate other tools or to command a robot. He must develop the other skills to be able to operate the new tools and new machines efficiently; (2) re-skilling: Industry 4.0 is expected to result in some job displacement. A great number of jobs will disappear, but a number of new jobs will appear. It was like that, with the carts, the horses, and the cars; (3) continuous learning: technologies will become quickly obsolete at a fast rate. New strategies for continuous professional development will be required, namely, to adapt to the enormous changes that technological advance- 
ment will need; (4) mind set change: the labor force will have to adapt to many changes, knowing that some of them will resist and will be against the implementation of newer technologies. This will require companies to plan for mind-set change of its employees. As such, it will be necessary to help them in a smooth transition to technologically advanced manufacturing processes.

To be competitive, today's companies must manufacture products of the highest quality in order to satisfy the increasing customer requirements, not only in relation to quality, but also in relation to the environment, sustainability, and social responsibility [18,41,42]. Thus, nowadays and in the future, quality of products, services, and processes is essential to creating value for organizations [43-45] and also, to achieving sustainable economic success and to ensure competitiveness [46-48] where the application of lean tools is important $[49,50]$. Hence, quality management has attracted the interest of many people, namely, quality professionals, managers, and academics [51], as a very important area of research [18] toward sustainability [52-54] and efficiency, where some problems may appear [55]. Hence, for any company, an important key to sustainable economic success is giving emphasis on quality management [56-58] today and in the future. Thus, related to its main concepts, such as, among others, Smart Factory, Cyber-Physical System, Internet of Things and Services, Industry 4.0 provides great opportunities for quality management [18,31], namely, Quality 4.0. Growing demand for products with quality above average and services at more competitive prices is directed to an increasingly competitive global marketplace reasoned by adaptability, agility, flexibility, and innovativeness. Over the past decades, businessmen have adopted quality management (QM) approaches, such as, initially, ISO 9001 and later, TQM, Six Sigma, lean production and in the near future, they must adopt Quality 4.0. Different QM awards were created in the USA, Europe, and Japan, to foster quality improvement by recognizing companies with quality excellence $[59,60]$. This recognition will remain, and is likely to increase, in Industry 4.0, and therefore with Quality 4.0. A dynamic stakeholder orientation wheel provides permanent inputs to the problem-solving process. The work environment that enhances intrinsic motivation leads to obtaining creativity benefits from all stakeholders. Hence, businessmen and managers should endeavor to match partner's and people's skills, interests, and personality types to the right work [61]. With this, a new paradigm emerges, that is, an emergent quality management (EQM) paradigm [62] which has already started to be called, by many professionals, as Quality 4.0. In their journey to adopt Industry 4.0 they are expected to encounter a number of challenges related to the skills level of their workforce. The skills which are important today will cease to be so in the future and it is expected that the workforce must possess new skills in the domain of information technology, data analytics, etc. A higher percentage of the actual and new jobs will give importance to cognitive abilities and system skills over physical abilities while defining core work-related skill sets [20], where emotional intelligence and its relationship to employability skills can play an important role [63]. But the skills gap across all industries are poised to grow in the so-called "Fourth Industrial Revolution." Rapid advances in artificial intelligence (AI), robotics, and other emerging technologies are happening in ever shorter cycles, changing the very nature of the jobs that need to be done and consequently, the skills needed to perform them faster than ever before [64].

As regards challenges related to skills, many developing countries have realized the importance of skills development in achieving economic development in the future and they have taken various measures to overtake the skill gap. From increasing education expenditure to an increasing network of vocational trainers by launching nation-wide programs, initiatives have been promoted to make the labor force industry-ready [20] for the next challenges where profitability, with help of Quality 4.0, is improved within Industry 4.0 route due to reduction in labor cost and in enhanced asset utilization rate. Profit margins are also improved, essentially due to the increase in the value of products as a result of the improvement in quality and flexibility of customization, as well as the decrease in labor costs. But according to PwC [65] adaptability is the key to the future. 
Adaptability -in organizations, individuals, and society—is essential for navigating the changes ahead. The skills needs are changing [66] and it is very difficult to predict exactly the skills that will be needed even five years from now.

Hence, workers, companies, and organizations need to be ready to quickly adapt, in each of the world we envisage. Inevitably, much of the responsibility will be on the individual businessperson, and also, on the worker. They must be willing to not only adapt to organizational change, but also to acquiring new skills and experiences throughout their lifetime, trying new jobs, new tasks, and even re-thinking and retraining mid-career. Governments and leaders of organizations of all kinds must do much to help: easing the routes to training and retraining, and encouraging and incentivizing adaptability and the critical and increasingly valued skills of leadership, creativity, and innovation [65].

\section{Methodology}

The main research question of the presented research is: Do quality management employees, of Portugal's North West region, have the perception of the impact of Industry 4.0 in the quality management profession and in the required and needed skills?

The research approach followed to attain the objectives of this work was the inductive one. Thus, researchers begin with important and specific observations, which are used to conceive some theories and conclusions. The reason for occupying the inductive approach was that it takes into account the work context where research is more active.

To make an exploratory analysis, it was used as the primary method of data compilation, a structured questionnaire. The selection of the respondents is representative of the population that works in some field of quality management. Thus, it was allowed to develop a descriptive research design. As referred by Kothari [67] and Michener [68], a structured survey allows us to quantify a multitude of data for further analysis. The use of the survey, as well as, the use of quantitative analysis of the data, with help of different statistical tools and methods, can be verified in a great variety of research work carried out under various studies about quality management, as well as, of its needs [69,70].

The main objectives of the survey are defined in this way: (1) To verify the importance of the implementation of the ISO 9001 standard and to know the main activities related to quality developed in the surveyed companies; (2) to characterize the identification of the main skills according to various factors such as age, level of education, gender, number of workers, degree of experience, and company size; and (3) to determine the main skills associated with quality management professionals. All the respondents were professionals who worked in quality management and develop their professional activity in various enterprises of Northern Portugal. It also must be noticed that the respondents' overall level of knowledge concerning Industry 4.0 was, at the time the survey, very much incipient, namely, lack of knowledge on the development and implementation of technologies in the production systems about Industry 4.0. Furthermore, we think it is at the global level, namely in Italy [71] and France [72], among other countries.

\section{The Survey Design}

A quantitative research design involving a questionnaire of this survey was distributed to a group of workers participating in a forum related to the management of quality.

The participants represent various types of companies and institutions. The questionnaire of the survey included different scales. The following objectives were highlighted: (1) Professional profile description of the workers, with the information based on years of experience in quality management, number of workers of the enterprise, and if there are different certifications at the enterprise; (2) the perception of the importance having implemented the ISO 9001 standard (Likert scale, classifying from "not so much important" to "very important"); (3) the most important and used quality techniques and tools by the professional workers (Binary scale, classing " 0 " as not using and " 1 " as using); and (4) the most relevant perceived competencies for future quality management professionals (Likert scale, classifying from to "no so much important" to "very important"). The analyzed 
sample was a more convenient possible sample of quality management workers, rather than, for instance, a random representative sample (a probability sample), due to, namely, budget and time constraints. After analyzing the answered questionnaires, 90 results were considered valid, reaching a confidence level of $95 \%$ with an error margin of $5 \%$. The surveys were conducted on men (43\%) and women (57\%) aged 20 to 60, maintaining the confidentiality and the personal anonymity of each participant. The sample mirrors, reasonably well, the universe of professionals that work in quality management.

\section{Results}

It is known that the main pillars of Industry 4.0 are (Figure 2), among others, Big Data and Analytics, Autonomous Robots, The Industrial Internet of Things, The Cloud Additive Manufacturing. Hence is necessary to have knowledge and understanding of ICT (Information and Communications Technology).

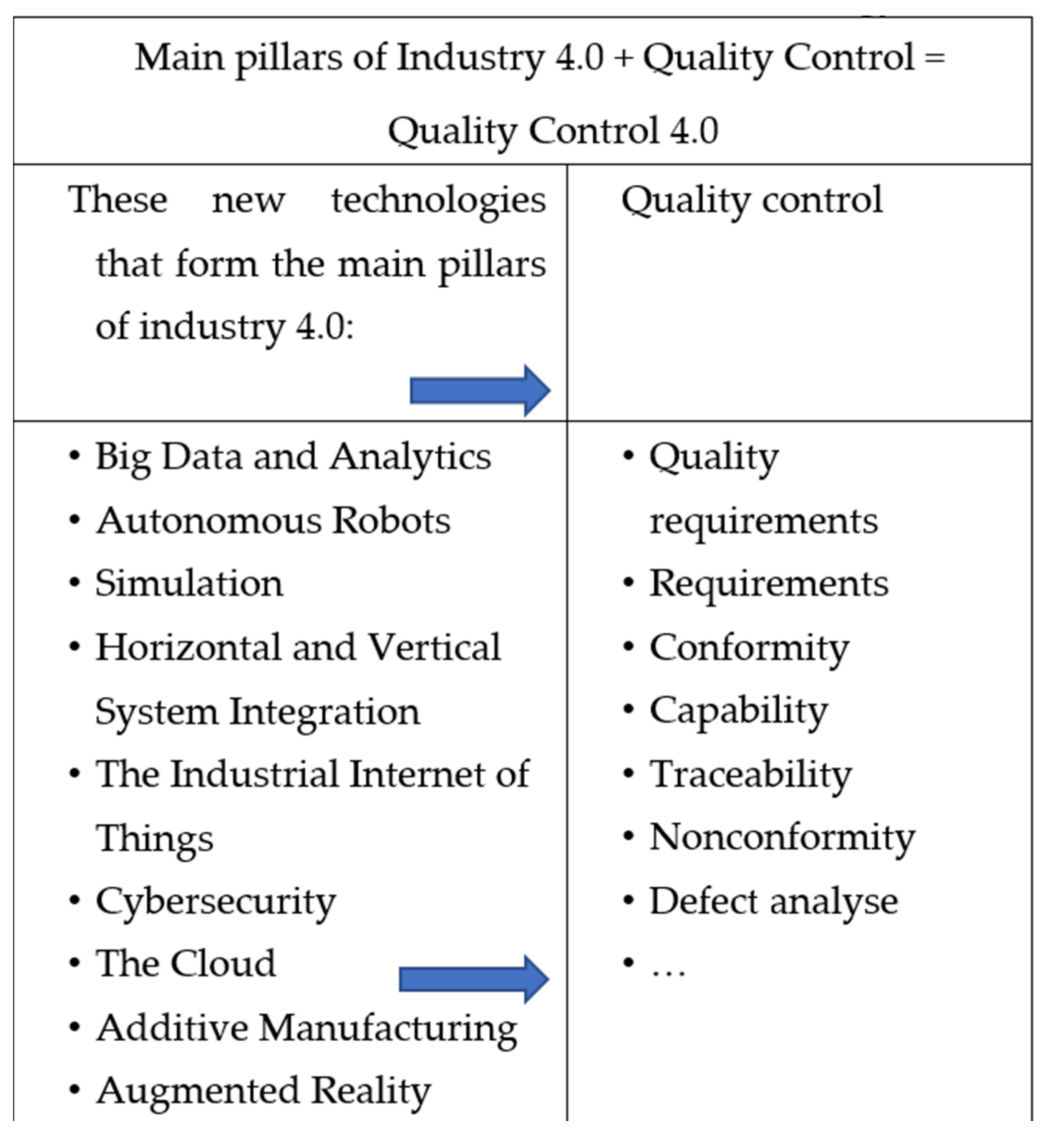

Figure 2. Main pillars of Industry 4.0.

To manage the Industry 4.0 quality requirements are necessary and fundamental, such as Conformity, Capability, Traceability, Nonconformity, Defect analysis (Figure 2). In Figure 3 the more important activities developed in the companies are represented, in which work, the people who responded to the survey. Most of the respondents are active workers in the Quality Management System, namely, among others, in quality auditing, continuous process improvement, 5 S implementation, ISO 9001:2015, metrology, standardized work, application of quality tools, and statistical process control. 


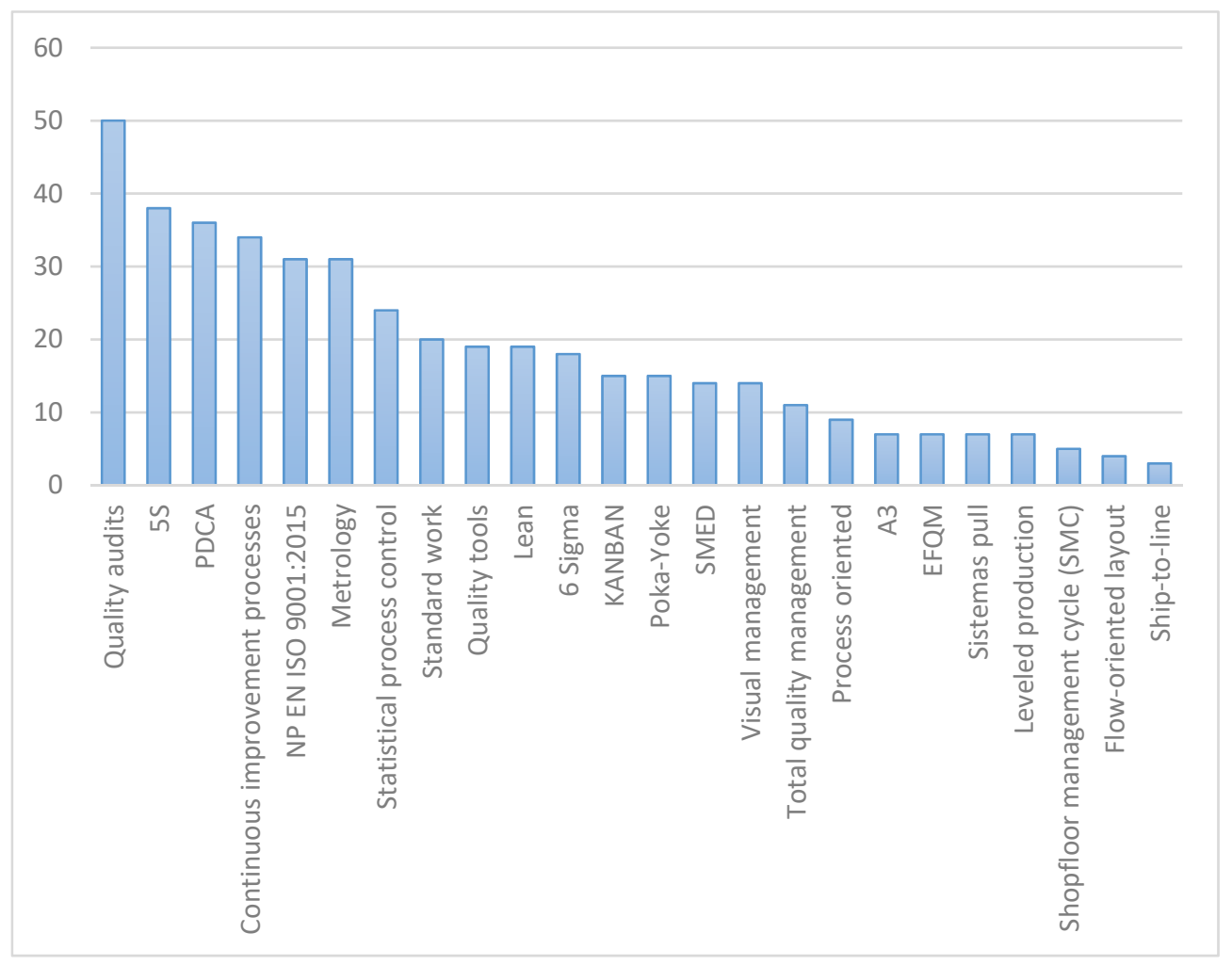

Figure 3. Main activities related to quality, developed in the surveyed companies [36].

This emphasizes the fact that the answers were given by people that work with other important quality tools in their enterprises and are able to understand the importance that the certification of Quality Management System, according to the ISO 9001, has on their everyday work. Next, we focus our attention on the QMS skills necessary to Industry 4.0. For such research, an index from 1 to 5, based on a Likert scale, where 1 represents "Not important" and 5 represents "Very important" was created. Thus, it was intended to choose good indicators. As such, the average of the index in each one of the activities of the enterprise, may be a good indicator on the global perception of the main elements of the sample, related to each one of the activities. Quality audits, $5 S$, continuous improvement, metrology and standard works are daily activities in the surveyed companies. We found that the majority are production only companies, which is why creativity and other activities, so important for the design of products, appear little valued in our study.

From our point of view, when we look at skills, we must understand that identifying the most important skills can give us some indication of how the standard can evolve.

According to our survey (Table 1) females choose communication, critical thinking, and teamwork as the most important skills. Male believe that the most important skills are leadership, openness to change, and teamwork. It is also possible to conclude that, in total average, the most important skill for male and female is communication, followed by critical thinking and teamwork. We found that, in our study, the skill "creativity" is little valued and appears in the last places. When the results presented are compared with the survey promoted by World Economic Forum [40], where "Analytical thinking and innovation" is the main trend for the most important skills for 2022, with creativity ranking as the third overall skill. The question is if developing countries only produce what developed countries conceive, for the production of goods creativity is less important than for their design and development. 
Table 1. Report about the main skills perceived by female and male.

\begin{tabular}{cccc}
\hline & Female & Male & Total \\
\hline Communication & 4.67 & 4.42 & 4.56 \\
Critical Thinking & 4.59 & 4.36 & 4.49 \\
Teamwork & 4.57 & 4.47 & 4.52 \\
Leadership & 4.39 & 4.53 & 4.45 \\
Openness to change & 4.48 & 4.53 & 4.50 \\
Motivation & 4.46 & 4.41 & 4.43 \\
Decision-making & 4.35 & 4.35 & 4.35 \\
Efficiency & 4.17 & 4.32 & 4.24 \\
Ethic & 4.22 & 4.11 & 4.17 \\
Customer orientation & 4.30 & 4.00 & 4.17 \\
Conflict management & 4.26 & 4.03 & 4.16 \\
Commitment & 4.13 & 4.14 & 4.13 \\
Assertiveness & 4.41 & 3.78 & 4.11 \\
Creativity & 3.98 & 4.27 & 4.09 \\
Emotional intelligence & 4.11 & 4.06 & 4.02 \\
Focus on results & 4.13 & 3.89 & 3.95 \\
Flexibility & 4.02 & 3.86 & 3.82 \\
Negotiation & 3.80 & 3.83 &
\end{tabular}

Concerning "Critical thinking," this skill is also in line with the ISO 9001 standard, because whenever it is important to improve the product or the process, it is also necessary to take into account the critical thinking when analyzing problems, thus allowing to find the correct solutions. The big difference is whether innovation refers to production processes, very common in developing countries, or to product innovation, more common in developed countries.

Chi-square tests were performed to see if any of the variables influenced the importance attributed to skills in quality management. It was found that gender does not significantly influence $(\alpha=0.1)$ the valuation of the different quality management skills.

With regard to schooling, we can see (Table 2) that non-graduates choose critical thinking, leadership, and decision-making as the most important skills. Graduate employees choose critical thinking, communication, and teamwork as the most important skills and postgraduate employees choose motivation, efficiency, and openness to change as the most important skills.

Table 2. Report about the main skills perceived by employers according to education level.

\begin{tabular}{ccccc}
\hline & $\begin{array}{c}\text { No } \\
\text { Graduation }\end{array}$ & $\begin{array}{c}\text { Graduate } \\
\text { Studies }\end{array}$ & $\begin{array}{c}\text { Postgraduate } \\
\text { Studies }\end{array}$ & Total \\
\hline Critical Thinking & 4.64 & 4.31 & 4.61 & 4.49 \\
Creativity & 4.14 & 4.26 & 3.94 & 4.11 \\
Leadership & 4.64 & 4.34 & 4.48 & 4.45 \\
Emotional intelligence & 4.36 & 4.03 & 4.03 & 4.09 \\
Decision-making & 4.57 & 4.31 & 4.29 & 4.35 \\
Negotiation & 3.50 & 4.09 & 3.67 & 3.82 \\
Customer orientation & 3.93 & 4.34 & 4.09 & 4.17 \\
Communication & 4.50 & 4.46 & 4.70 & 4.56 \\
Teamwork & 4.50 & 4.40 & 4.67 & 4.52 \\
Focus on results & 3.79 & 4.03 & 4.12 & 4.02 \\
Conflict management & 3.93 & 4.29 & 4.12 & 4.16 \\
Ethic & 3.86 & 4.34 & 4.12 & 4.17 \\
Assertiveness & 4.07 & 4.29 & 4.00 & 4.13 \\
Commitment & 4.21 & 4.17 & 4.06 & 4.13 \\
Motivation & 4.50 & 4.54 & 4.29 & 4.43 \\
Flexibility & 4.07 & 4.06 & 3.79 & 3.95 \\
Efficiency & 4.36 & 4.40 & 4.03 & 4.24 \\
Openness to change & 4.64 & 4.54 & 4.39 & 4.50 \\
\hline
\end{tabular}


Concerning the education levels, we already have statistical evidence of their dependence on the value given to customer orientation. According to Table 3, we can see that this dependence comes from the fact that people with higher qualifications and training give greater importance to this skill.

Table 3. Chi-square test about the main skills perceived by employers according to different schooling.

\begin{tabular}{cccccc}
\hline & & \multicolumn{3}{c}{ Education Levels } & \multirow{2}{*}{ Total } \\
\cline { 3 - 5 } & & Not Graduate & Graduate & Postgraduate & \\
\hline \multirow{2}{*}{$\begin{array}{c}\text { Customer } \\
\text { Orientation }\end{array}$} & 3.00 & 4 & 6 & 7 & 17 \\
& 4.00 & 7 & 7 & 13 & 27 \\
\multicolumn{2}{c}{ Total } & 5.00 & 3 & 35 & 34 \\
\hline
\end{tabular}

According to Table 4, it is interesting to note that the highest values of the competence importance index are attributed to people with less experience. In addition, we can see that people with more experience have higher rates than those with experience between 3 and 5 years. On the other hand, the most important skills for people with less than 3 years of experience are: communication, teamwork, and openness to change. For people with experience between 3 and 5 years, the most important skills are: leadership, communication, and motivation. For people with more than 5 years of experience, the most important skills are: critical thinking and openness to change.

Table 4. Report about the main skills perceived by employers according to different years of experience.

\begin{tabular}{ccccc}
\hline & $\begin{array}{c}\text { Less than } \mathbf{3} \\
\text { Years }\end{array}$ & $\begin{array}{c}\text { Between 3 and 5 } \\
\text { Years }\end{array}$ & $\begin{array}{c}\text { More than } \mathbf{5} \\
\text { Years }\end{array}$ & Total \\
\hline Critical Thinking & 4.59 & 4.00 & 4.50 & 4.49 \\
Creativity & 4.32 & 3.64 & 3.86 & 4.11 \\
Leadership & 4.51 & 4.45 & 4.32 & 4.45 \\
Emotional intelligence & 4.14 & 3.64 & 4.18 & 4.09 \\
Decision-making & 4.50 & 4.00 & 4.18 & 4.35 \\
Negotiation & 3.94 & 3.27 & 3.82 & 3.82 \\
Customer orientation & 4.10 & 4.18 & 4.32 & 4.17 \\
Communication & 4.61 & 4.64 & 4.41 & 4.56 \\
Teamwork & 4.63 & 4.27 & 4.41 & 4.52 \\
Focus on results & 4.20 & 3.18 & 4.05 & 4.02 \\
Conflict management & 4.22 & 3.82 & 4.18 & 4.16 \\
Ethic & 4.24 & 4.00 & 4.09 & 4.17 \\
Assertiveness & 4.20 & 3.91 & 4.09 & 4.13 \\
Commitment & 4.37 & 3.73 & 3.82 & 4.13 \\
Motivation & 4.50 & 4.36 & 4.32 & 4.43 \\
Flexibility & 4.06 & 3.27 & 4.05 & 3.95 \\
Efficiency & 4.44 & 3.73 & 4.05 & 4.24 \\
Openness to change & 4.63 & 4.18 & 4.36 & 4.50 \\
\hline
\end{tabular}

It was verified that there exists a dependence between the number of years of experience in the company and the importance given to focus on results. By analyzing Table 5, it is possible to see that people with less experience value this competence more. By analyzing Table 6, it is possible to understand motivation perceived by employers. 
Table 5. Chi-square test about the skill "Focus on results" perceived by employers according to different years of experience.

\begin{tabular}{ccccc}
\hline & & \multicolumn{3}{c}{ Experience } \\
\cline { 3 - 5 } & & Less than 3 Years & More than 3 Years & Total \\
\hline \multirow{3}{*}{ Focus on results } & 3.00 & 6 & 10 & 16 \\
& 4.00 & 22 & 9 & 31 \\
& 5.00 & 21 & 14 & 35 \\
\hline \multicolumn{2}{c}{ Total } & & 49 & 33 \\
\hline
\end{tabular}

Table 6. Chi-square test about the skill "Motivation" perceived by employers according to different years of experience.

\begin{tabular}{|c|c|c|c|c|}
\hline & & \multicolumn{3}{|c|}{ Experience } \\
\hline & & 1.00 & 2.00 & Total \\
\hline \multirow{3}{*}{ Motivation } & 3.00 & 4 & 6 & 10 \\
\hline & 4.00 & 15 & 4 & 19 \\
\hline & 5.00 & 31 & 23 & 54 \\
\hline \multicolumn{2}{|c|}{ Total } & 50 & 33 & 83 \\
\hline
\end{tabular}

Motivation also has a dependency on years of working experience and through the table, we can see that people with more experience are those who most value this skill.

Regarding the number of employees in the company, as shown by Table 7, we can see that the skills most valued in small businesses are efficiency, openness to change, and critical thinking (these companies may have a greater need for adaptation). For companies that have between 11 and 49 employees, the skills most valued are communication, openness to change, and critical thinking (the same as small companies). For companies with between 50 and 250 employees, the skills most valued are motivation, communication, and teamwork. In companies with more than 250 employees the skills most valued are decision-making, teamwork, and critical thinking.

Table 7. Report about the main skills perceived by employers according to the number of company workers.

\begin{tabular}{cccccc}
\hline & \multicolumn{5}{c}{ Number of Company Workers } \\
\cline { 2 - 5 } & $\begin{array}{c}\text { Less than } \\
\mathbf{1 0}\end{array}$ & $\begin{array}{c}\text { Between } \mathbf{1 1} \\
\text { and } \mathbf{4 9}\end{array}$ & $\begin{array}{c}\text { Between } \\
\mathbf{5 0} \text { and 250 }\end{array}$ & $\begin{array}{c}\text { More than } \\
\mathbf{2 5 0}\end{array}$ & Total \\
\hline Critical Thinking & 4.64 & 4.56 & 4.35 & 4.49 & 4.49 \\
Creativity & 4.27 & 4.06 & 4.45 & 3.89 & 4.11 \\
Leadership & 4.45 & 4.31 & 4.60 & 4.43 & 4.45 \\
Emotional intelligence & 4.27 & 3.94 & 3.90 & 4.20 & 4.09 \\
Decision-making & 4.55 & 4.13 & 4.05 & 4.56 & 4.35 \\
Negotiation & 4.36 & 3.75 & 3.55 & 3.83 & 3.82 \\
Customer orientation & 4.45 & 3.94 & 4.20 & 4.17 & 4.17 \\
Communication & 4.45 & 4.75 & 4.70 & 4.43 & 4.56 \\
Teamwork & 4.45 & 4.38 & 4.70 & 4.51 & 4.52 \\
Focus on results & 4.27 & 3.88 & 3.80 & 4.14 & 4.02 \\
Conflict management & 4.45 & 3.81 & 4.30 & 4.14 & 4.16 \\
Ethic & 4.55 & 4.31 & 4.05 & 4.06 & 4.17 \\
Assertiveness & 4.55 & 4.19 & 4.30 & 3.89 & 4.13 \\
Commitment & 4.36 & 4.19 & 3.75 & 4.26 & 4.13 \\
Motivation & 4.45 & 4.25 & 4.75 & 4.33 & 4.43 \\
Flexibility & 4.00 & 3.81 & 3.85 & 4.06 & 3.95 \\
Efficiency & 4.73 & 4.06 & 4.00 & 4.31 & 4.24 \\
Openness to change & 4.73 & 4.69 & 4.45 & 4.37 & 4.50 \\
\hline
\end{tabular}


Chi-square test, according to the number of employees in the company, does not show any dependence on the importance given to each of the skills.

According to Table 8, it is possible to conclude that the most important skills for people that work in companies without ISO 9001 certification are Assertiveness, Critical Thinking and Openness to change. Regarding people that work in companies with ISO 9001 certification, the most important skills are Communication, Teamwork, and Openness to change.

Table 8. Report about the main skills perceived by employers according to if the company is ISO 9001 certified or not.

\begin{tabular}{cccc}
\hline & \multicolumn{3}{c}{ The Company Is ISO 9001 Certified } \\
\cline { 2 - 4 } & No & Yes & Total \\
\hline Critical Thinking & 4.50 & 4.48 & 4.49 \\
Creativity & 4.18 & 4.06 & 4.11 \\
Leadership & 4.35 & 4.52 & 4.45 \\
Emotional intelligence & 3.97 & 4.17 & 4.09 \\
Decision-making & 4.18 & 4.47 & 4.35 \\
Negotiation & 3.82 & 3.81 & 3.82 \\
Customer orientation & 4.09 & 4.22 & 4.17 \\
Communication & 4.35 & 4.71 & 4.56 \\
Teamwork & 4.32 & 4.67 & 4.52 \\
Focus on results & 3.68 & 4.27 & 4.02 \\
Conflict management & 4.00 & 4.27 & 4.16 \\
Ethic & 4.18 & 4.17 & 4.17 \\
Assertiveness & 4.53 & 3.85 & 4.13 \\
Commitment & 4.12 & 4.15 & 4.13 \\
Motivation & 4.29 & 4.53 & 4.43 \\
Flexibility & 3.62 & 4.19 & 3.95 \\
Efficiency & 4.03 & 4.39 & 4.24 \\
Openness to change & 4.41 & 4.56 & 4.50 \\
\hline
\end{tabular}

From Table 9, it is possible to observe that the company's certification is dependent on the importance given to focus on results. In this case, there is a clear tendency for people who are part of certified companies to attach greater importance to this skill.

Table 9. Chi-square test about the skill "Focus on results" perceived by employers according to if the company is ISO 9001 certified.

\begin{tabular}{ccccc}
\hline & & \multicolumn{3}{c}{ The Company Is ISO 9001 Certified } \\
\cline { 3 - 5 } & & No & Yes & Total \\
\hline \multirow{3}{*}{ Focus on results } & 3.00 & 11 & 5 & 16 \\
& 4.00 & 11 & 20 & 31 \\
& 5.00 & 12 & 23 & 35 \\
\hline \multicolumn{2}{c}{ Total } & 34 & 48 & 82 \\
\hline
\end{tabular}

Also, concerning the motivation skill (Table 10), there is a dependence between the existence of ISO 9001 certification. Although highly valued in both groups, it is in the group of people who work in certified companies that greater importance is given to this skill. 
Table 10. Chi-square test about the skill "Motivation" perceived by employers according to if the company is ISO 9001 certified.

\begin{tabular}{ccccc}
\hline & & \multicolumn{3}{c}{ The Company Is ISO 9001 Certified 9001 } \\
\cline { 3 - 5 } & & No & Yes & Total \\
\hline \multirow{3}{*}{ Motivation } & 3.00 & 7 & 3 & 10 \\
& 4.00 & 5 & 14 & 19 \\
& 5.00 & 22 & 32 & 54 \\
\hline \multirow{3}{*}{ Total } & & 34 & 49 & 83 \\
\hline
\end{tabular}

Among the people who work in companies with ISO 9001 certification, according to Table 11, we can see that the duration of the certification has little influence on the importance attributed to each one of the skills.

Table 11. Report about the main skills perceived by employers according to the Number of years of ISO 9001 certification.

\begin{tabular}{|c|c|c|c|c|c|}
\hline & \multicolumn{5}{|c|}{ Number of Years of ISO 9001 Certification } \\
\hline & $\begin{array}{c}\text { Less than } 3 \\
\text { Years }\end{array}$ & $\begin{array}{l}\text { Between } 3 \\
\text { and } 5 \text { Years }\end{array}$ & $\begin{array}{l}\text { Between } 6 \\
\text { and } 10 \text { Years }\end{array}$ & $\begin{array}{l}\text { More than } \\
10 \text { Years }\end{array}$ & Total \\
\hline $\begin{array}{l}\text { Critical } \\
\text { Thinking }\end{array}$ & 4.63 & 4.29 & 4.44 & 4.63 & 4.53 \\
\hline Creativity & 4.50 & 4.00 & 4.33 & 3.85 & 4.09 \\
\hline Leadership & 4.50 & 4.14 & 4.56 & 4.63 & 4.51 \\
\hline $\begin{array}{l}\text { Emotional } \\
\text { intelligence }\end{array}$ & 4.38 & 3.86 & 4.11 & 4.32 & 4.21 \\
\hline $\begin{array}{l}\text { Decision- } \\
\text { making }\end{array}$ & 4.75 & 4.00 & 4.67 & 4.50 & 4.50 \\
\hline Negotiation & 4.25 & 3.29 & 4.33 & 3.68 & 3.86 \\
\hline $\begin{array}{l}\text { Customer } \\
\text { orientation }\end{array}$ & 4.00 & 3.86 & 4.78 & 4.30 & 4.27 \\
\hline Communication & 5.00 & 4.57 & 5.00 & 4.63 & 4.77 \\
\hline Teamwork & 4.88 & 4.57 & 4.89 & 4.68 & 4.74 \\
\hline $\begin{array}{l}\text { Focus on } \\
\text { results }\end{array}$ & 3.75 & 3.57 & 4.78 & 4.53 & 4.28 \\
\hline $\begin{array}{c}\text { Conflict } \\
\text { management }\end{array}$ & 4.00 & 4.00 & 4.67 & 4.42 & 4.33 \\
\hline Ethic & 4.13 & 4.43 & 4.33 & 4.05 & 4.19 \\
\hline Assertiveness & 3.75 & 3.43 & 4.44 & 3.84 & 3.88 \\
\hline Commitment & 4.13 & 3.43 & 4.44 & 4.21 & 4.12 \\
\hline Motivation & 4.75 & 4.71 & 4.67 & 4.40 & 4.57 \\
\hline Flexibility & 4.25 & 3.71 & 4.67 & 4.21 & 4.23 \\
\hline Efficiency & 4.38 & 4.29 & 4.56 & 4.35 & 4.39 \\
\hline $\begin{array}{l}\text { Openness to } \\
\text { change }\end{array}$ & 4.75 & 4.57 & 4.78 & 4.47 & 4.60 \\
\hline
\end{tabular}

It is also possible to conclude, according to Table 12, that the skills most valued by people who work in companies that do not have other certifications are Communication, Teamwork, Motivation, and Openness for Change. Among the people who work in companies that do have additional certifications, the most valued skills are Leadership, Critical Thinking, and Decision Making. 
Table 12. Report about the main skills perceived by employers according to if there are others certifications.

\begin{tabular}{cccc}
\hline & \multicolumn{3}{c}{ Companies Have Other Certifications } \\
\cline { 2 - 4 } & No & Yes & Total \\
\hline Critical Thinking & 4.41 & 4.62 & 4.49 \\
Creativity & 4.24 & 3.88 & 4.10 \\
Leadership & 4.29 & 4.69 & 4.44 \\
Emotional intelligence & 3.94 & 4.31 & 4.09 \\
Decision-making & 4.18 & 4.61 & 4.35 \\
Negotiation & 3.82 & 3.81 & 3.81 \\
Customer orientation & 4.02 & 4.42 & 4.18 \\
Communication & 4.53 & 4.59 & 4.56 \\
Teamwork & 4.51 & 4.56 & 4.53 \\
Focus on results & 3.86 & 4.25 & 4.01 \\
Conflict management & 4.08 & 4.28 & 4.16 \\
Ethic & 4.27 & 4.06 & 4.19 \\
Assertiveness & 4.27 & 3.94 & 4.14 \\
Commitment & 4.04 & 4.25 & 4.12 \\
Motivation & 4.51 & 4.33 & 4.44 \\
Flexibility & 3.84 & 4.16 & 3.96 \\
Efficiency & 4.18 & 4.30 & 4.23 \\
Openness to change & 4.55 & 4.41 & 4.49 \\
\hline
\end{tabular}

According to Table 13, the existence of other certifications is dependent on the importance attributed to Ethics, and it is in companies without other certifications that the greatest importance is given to this competence.

Table 13. Chi-square test about the skill "Ethic" perceived by employers according to if companies have other certifications.

\begin{tabular}{ccccc}
\hline & & \multicolumn{3}{c}{ Companies Have Other Certifications } \\
\cline { 3 - 5 } & & Yes & No & Total \\
\hline \multirow{3}{*}{ Ethic } & 3.00 & 9 & 6 & 15 \\
& 4.00 & 9 & 14 & 23 \\
& 5.00 & 31 & 12 & 43 \\
\hline \multirow{3}{*}{} & & 49 & 32 & 81 \\
\hline
\end{tabular}

There is also a dependency between the existence of other certifications and the importance attached to Flexibility. Table 14 shows that it is in companies with other certifications that the highest importance is attached to this competence.

Table 14. Chi-square test about the skill "Flexibility" perceived by employers according if companies have other certifications.

\begin{tabular}{ccccc}
\hline \multirow{3}{*}{} & & \multicolumn{3}{c}{ Companies That Have Other Certifications } \\
\cline { 3 - 5 } & & Not & Yes & Total \\
\hline \multirow{3}{*}{ Flexibility } & 3.00 & 17 & 5 & 22 \\
& 4.00 & 12 & 15 & 27 \\
& 5.00 & 20 & 12 & 32 \\
\hline & & 49 & 32 & 81 \\
\hline
\end{tabular}

\section{Discussion}

Industry 4.0, is also known as the fourth industrial revolution. Many people still do not understand it, namely how it will impact our life. Quality Management is no 
exception and it will be, also, a challenge. Hence, Quality 4.0 strategy appear as an excellent opportunity to realign quality to corporate strategy. Many enterprises have strategic objectives related, namely, to Big Data and Industry 4.0, often showing quality improvement use cases [3]. In a general way, trending skills demand to 2022 such as presented in Figure 1, [40], are necessary. But for Quality 4.0, in addition, it is necessary to have skills in new technologies such as, for instance Big Data and to know how to collect and filter all information and make the best decisions according to the information that these data provide. For that, it is necessary to be a leader, to have analytical thinking, to have creativity, originality and initiative, and sometimes to be capable of complex problem-solving with emotional intelligence.

Many things were exposed about the need for innovation in all type of organizations. It is known that quality management can play an important role in the way of improvement, namely identifying innovative paths to provide a better workplace culture [39]. Thus, it is known that traditional QM practices showed to be inefficient when applied in the context of complex processes [73]. Hence, some authors, such as Brown [39], Antony [74], Shin et al. [75], among others, explore the future direction of the quality movement, which will have to take into account the quality of products manufactured [76] in the era of the digital economy [77,78], that is related to Industry $4.0[31,79-83]$, with a lot of influence on the future of employment [11].Thus, the direction of quality in the future is then explored by identifying a big number of questions that have probably a great impact on quality in most of the organizations. But according to others researchers, such as Liao et al. [84], the main research directions of quality management and the current research efforts, allow us to disclose this state-of-the-art: if on the one hand, (1) the research directions that have already attracted more research efforts, such as, Reference Architecture and Standardization, Vertical and Horizontal Integration; and for on the other hand (2) the research directions that refer insufficient, or even the lack of skills research efforts, such as the End-to-End Digital Integration, or even Regulatory Framework. Thus, according to $\mathrm{Xu}$ et al. [59], Quality Management (QM) research has been many times directed to investigating the QM system, while a collective approach of the effects of individual QM practices on organizational performance remains as a poor area of research.

Brown [39] states that a challenge for the quality movement in the future, will be a market of ideas, but many workers and managers will see quality management, only as compliance. With regards to Big Data, it will be an important change for the way much of the world's commercial relationships of companies are done and it could be a challenge to human behavior similar to the industrial revolution of the nineteenth century. The future professionals of quality should be leaders who understand how Big Data is evaluated and analyzed. Certainly there will appear new tools of data analysis and inference required to use Big Data effectively. Quality education programs must recognize this and modify their curricula according to the new needs. Top management must offer workplaces that provide empowerment, encourage and facilitate creativity and personal initiative, as well as, continuous improvement that will be fundamental in this issue [39]. As quality professionals will go into this new era, it is very important to have a solid understanding of the main aspects of Industry 4.0, as well as, Smart Factory 4.0, its implications in all aspect of production, the extended supply chain and therefore, their Quality Management System [85]. When quality professionals will go into this new era, it is very important to have a solid understanding of the main aspects of Industry 4.0, as well as, Smart Factory 4.0 and respective implications in all aspect of production, in the extended supply chain and therefore, in their Quality Management System [85].

Our study is in line with Murugiah's [86], where it is stated that the shift required in education for sustainable development is to catch up the need for the 21st century skills (21CS) competencies in problem-solving, collaboration, critical thinking, and communication. It is also in line with Blanchet et al. [87], when they state that regarding skills, interdisciplinary thinking is the key. The dominant technologies of Industry 4.0 will be information and communication technologies (ICT), electronics and robotics in embedded 
systems. But it will, clearly, also embrace other knowledge areas such as biotech and nanotech. It is to be expected that businesses in Industry 4.0 need both enhanced social and technical skills. There will be a shift in design thinking instead of production thinking. Our study is also in line with Cotet et al.'s [88], where these authors state that the three top employees' soft skills required in an Industry 4.0 are creativity, emotional intelligence, and proactive thinking. The authors' understanding is that those three top skills assist an employee to adapt easily to the incremental changes that are a full characteristic of the nature of Industry 4.0 technologies. Our study is also in line with other studies such as Maisiri et al. [89] and Jacob [3], where it is stated that Quality leaders should give priority to Quality 4.0 plans. Our study also reveals, that, while the respondents are not very familiarized with the Industry 4.0, these quality management professionals perceive that the skills needed and required for their profession must be adapted to the new digitalization era, allowing the sustainable development of smart industries and the Industry 4.0, and the introduction of the Quality 4.0 concept within their companies.

According to Antony [74] "as the global economic forces were radically changing, it is essential that quality managers face the future with quality-based integrated management programmes that fit the new business era rather than continuing with systems that may have worked in the past". Employees are intelligent and they have seen it all before. Sometimes, it is difficult to involve them. But the beacon of light is that there are organizations that have quality as integral to their culture and look for success in their respective markets [33,90-93]. There are organizations that have found niche markets where their quality policies pay dividends. These are the smart ones [39]. According to Antony [74] for this, quality professionals should maintain cross-disciplinary networks, including great collaboration with stakeholders, science world, expertise communities, standardization organizations, benchmarking partners, and national quality movements.

The era of Industry 4.0 is coming, and its quality equivalent, Quality 4.0, is going to leave important marks on the industry. Quality's participation in Industry 4.0 has important benefits. It has been estimated that by embracing and participating in the technologies, data availability, and other elements of Industry 4.0, Quality 4.0, and the practical quality management application, EQM 4.0, manufacturers can potentially reduce their total cost of quality by 22 to $50 \%$ [85]. Big Data and analytics will help in decision-making support and will allow to optimize quality of production, save energy, and improve equipment efficiency. Augmented reality systems are based on supporting a variety of services, such as, for example, selecting parts in a warehouse or in supporting equipment maintenance. This technology at the service of production management is at an early stage. In the future, companies will give augmented reality broader importance, to provide workers with realtime information in order to improve decision-making and work procedures. Additive manufacturing, supported in 3D printing, is currently used mainly for the creation of prototypes and the production of individual components. With Industry 4.0, all the cited technology will be largely used to produce small batches of special products, namely the customized ones. It will be possible to have decentralized, high-quality additive production systems, reducing transport and storage distances. But what about cost? It is known that there are number of drivers and barriers in the implementation of the concept of Industry 4.0. One of the major strategic driver is a cost reduction [94]. On the other hand, one of the main barriers from managerial perspective is shortage of financial [95] and human resources. Different authors, such as Tortora et al. [71] and Chengula et al. [72], also mentioned that another important barrier is lack of qualified work force and lack of knowledge on the development and implementation of technologies in the production systems about Industry 4.0. According to different researches and experiences in implementation of the complex systems such as technologies, as well as concept described as Industry 4.0 two things are necessary [96]: investment in technologies, as well as investment in human resources and knowledge. It is clear that for both target, investments are needed and it is especially sensitive when it comes to small- and medium-sized companies. Generally, all over the world, small- and medium-sized enterprises often do not have sufficient funds to 
invest in the latest technologies and must allocate capital very effectively and carefully [96]. Another problem for all companies is the cost of obtaining funds for a specific investment in Industry 4.0 technologies. When it comes to Industry 4.0 the costs of technology decrease. For instance, one of the important components, IoT, is expected to grow rapidly, enabled by decrease in sensor costs [97]. These new technologies that form the main pillars of Industry 4.0 are among others [98,99]: Big Data and Analytics, Autonomous Robots, Simulation, Horizontal and Vertical System Integration, The Industrial Internet of Things, Cybersecurity, The Cloud, Additive Manufacturing, Augmented Reality, also have been decreasing in price. The second important cluster of costs is human resources. Generally, most of the projects of implementation of ISO 9001 starts with training the staff, starting from the general managers, quality managers and engineers and ending with training the complete working staff. The proper implementation of ISO standards reduces operating costs in an organization by an average of 10 per cent (according to British Standards Institution). In period of transition and implementation of the new technologies or the new concepts, companies often face different issues concerning human resources: employees need to acquire new competences and knowledge, there is usually lack of specific profiles of employees in the labor market. We believe that transformation from the existing systems to the advanced systems such as Industry 4.0 and in this case Quality 4.0 should start from defining and acquiring the needed quality management skills for quality managers 4.0. This approach demands the first investments should go to the upgrade of specific skills for quality managers, then they will have the opportunity to perform both organizational transformation based on the process approach as well as selection of the new technologies more efficiently having in mind the right goals. For sure the companies will face increasing investments in the first step (we are suggesting the investments in human resources, in this case quality manager, with the aim to get new knowledge and skills necessary for needed industrial transformation). In the second step companies will have investments in technology [100] (we are witnessing the cost of needed technology decreases), also all companies, especially SME will have difficulties obtaining financial resources but benefits coming from Industry 4.0 implementation are: reduced waste in operation costs, reduced labor costs, higher level of productivity, more efficient supply chains, Big Data management, improvement of product quality [101], and therefore increased revenues and profits [102].

The coming opportunity is very exciting. While the results are not achieved easily, now is time to determine if the organization's Quality investments are in line with its Industry 4.0 and Quality 4.0 strategies. Getting organizational support for investments in Quality Management and EQM 4.0 technologies, by demonstrating how those technologies will improve quality in the production, is critical to success [85] of the industry and of quality. However, some questions arise, for example, how do different cultures see the future of quality? How do organizations operating in diverse cultural contexts adopt quality principles? Can the same tools, processes, and techniques which work well in companies in the USA or Europe, be applied with good results in China? These are also some important challenges, among others [103] faced by multinational companies. Many have found that works, tools, and ideas, in the home country fail when are introduced in other countries [39]. As limitations of this research, we can highlight the low number of responses from quality professionals covering only the northern area of Portugal. In the future it should be extended to more quality professionals, working in other countries.

\section{Conclusions}

The world is more and more dynamic and things are nowadays rapidly changing. The only permanent situation over time is changes. The skills needs are changing [66] and it is very difficult to foresee the skills that will be necessary for people that will work in quality management, in even five or seven years from now, but we try to see something forward. Hence, people that work as professionals of quality management, must be seen as an important part of the change. This is an ongoing challenge. If an organization wishes to 
compete on quality and innovation as an important strategic weapon in the future, then it is very important to ensure that the top management supports the quality professionals.

According to our survey, and also in line with the WEF [40], quality professionals in the future, that is, Quality 4.0 professionals must have skills such as, creative thinking, be leaders, know how to communicate, and work as a team. Besides that, they must have knowledge of new technologies, that is cyber-physical production systems and combine that with the best quality management practices, where their decisions will be based on Big Data.

They must know how to motivate their work teams, be open to change, know how to make decisions and above all, they must know how to manage conflicts and they have to understand how to control their own emotions. It also must be noticed that in the future, the exchange of ideas will take precedence over the exchange of goods. Hence, one of the main skills of any quality professional for Quality 4.0 will be creativity. They must have the ability to adapt to changes and challenges that arise. In addition, they should acquire knowledge about new technologies, as they appear. Thus, top management must provide an environment in the organization where quality professionals are able to become excellent professionals in the process, who are able to make right decisions based on and supported by data analysis. In addition, quality professionals must promote the design and production of first-class products, be the defenders of their customers within the organization and, finally, they must create value for the stakeholders. As direction of future works, the authors have the idea of extending it to more quality professionals in more countries, in order to know better and consolidate the skills needed for quality professionals in the future of a changing world.

Author Contributions: This research had the collaboration of several authors. Conceptualization, L.B. and J.C.S.; methodology, F.C.; software, L.B.; validation, G.S. and M.J.F.; formal analysis, M.D.; investigation, G.S. and J.C.S.; resources, L.B.; data curation, F.C.; writing-original draft preparation, G.S. and M.J.F.; supervision K.Z. and M.S.; project administration, L.B.; All authors have read and agreed to the published version of the manuscript.

Funding: This research received no external funding.

Institutional Review Board Statement: Not applicable.

Informed Consent Statement: Informed consent was obtained from all subjects involved in the study.

Acknowledgments: The authors would like to thank all the quality professionals who responded to the survey that allowed this survey.

Conflicts of Interest: The authors declare no conflict of interest.

\section{References}

1. Drath, R.; Horch, A. Industrie 4.0: Hit or Hype? [Industry Forum]. IEEE Ind. Electron. Mag. 2014, 8, 56-58. [CrossRef]

2. Zonnenshain, A.; Kenett, R.S. Quality 4.0-The challenging future of quality engineering. Qual. Eng. 2020, 32, 614-626. [CrossRef]

3. Jacob, D. Quality 4.0 Impact and Strategy Handbook. Getting Digitally Connected to Transform Quality Management; LNS Research: Cambridge, UK, 2017.

4. Buchi, G.; Cugno, M.; Castagnoli, R. Smart factory performance and Industry 4.0. Technol. Forecast. Soc. Chang. 2020, 150, 119790. [CrossRef]

5. Weber, K.M.; Gudowsky, N.; Aichholzerb, G. Foresight and technology assessment for the Austrian Parliament-Finding new ways of debating the future of industry 4.0. Futures 2019, 109, 240-251. [CrossRef]

6. Culot, G.; Orzes, G.; Sartor, M.; Nassimbeni, G. The future of manufacturing: A Delphi-based scenario analysis on Industry 4.0. Technol. Forecast. Soc. Chang. 2020, 157, 120092. [CrossRef]

7. Horváth, D.; Szabó, R.Z. Driving forces and barriers of Industry 4.0: Do multinational and small and medium-sized companies have equal opportunities? Technol. Forecast. Soc. Chang. 2019, 146, 119-132. [CrossRef]

8. Lu, H.-P.; Weng, C.-I. Smart manufacturing technology, market maturity analysis and technology roadmap in the computer and electronic product manufacturing industry. Technol. Forecast. Soc. Chang. 2018, 133, 85-94. [CrossRef]

9. Zgodavova, K.; Bober, P.; Majstorovic, V.; Monkova, K.; Santos, G.; Juhaszova, D. Innovative methods for small mixed batches production system improvement: The case of a bakery machine manufacturer. Sustainability 2020, 12, 6266. [CrossRef] 
10. Li, L. China's manufacturing locus in 2025: With a comparison of "Made-in-China 2025" and "Industry 4.0". Technol. Forecast. Soc. Chang. 2018, 135, 66-74. [CrossRef]

11. Frey, C.B.; Osborne, M.A. The future of employment: How susceptible are jobs to computerisation? Technol. Forecast. Soc. Chang. 2017, 114, 254-280. [CrossRef]

12. Blass, E.; Hackston, J. Future skills and current realities. How the psychological (Jungian) type of European business leaders relates to the needs of the future. Futures 2008, 40, 822-833. [CrossRef]

13. Lianaki-Dedouli, I.; Plouin, J. Bridging anticipation skills and intercultural competences as a means to reinforce the capacity of global citizens for learning to learn together. Futures 2017, 94, 45-58. [CrossRef]

14. Morrar, R.; Arman, H.; Mousa, S. The fourth industrial revolution (Industry 4.0): A social innovation perspective. Technol. Innov. Manag. Rev. 2017, 7, 12-20. [CrossRef]

15. Aldag, M.C.; Eker, B. What is Quality 4.0 in the era of industry 4.0? In Proceedings of the 3rd International Conference on Quality of Life, Kopaonik, Serbia, 28-30 November 2018; Center for Quality, Faculty of Engineering, University of Kragujevac: Kopaonik, Serbia, 2018; pp. 31-33.

16. Chopra, A. AI in Supply \& Procurement. In Proceedings of the Amity International Conference on Artificial Intelligence (AICAI), Dubai, United Arab Emirates, 4-6 February 2019. [CrossRef]

17. Sütőová, K.; Zgodavová, K. Maturity of Automotive Industry 4.0 and Quality 4.0 Intelligent Technology in Slovakia: Future of Needs for Learning and Development. In Proceedings of the QMOD-ICQSS Conference 2019: Leadership and Strategies for Quality, Sustainability and Innovation in the 4th Industrial Revolution, Krakow, Poland, 13-15 October 2019; Lund University Library Press: Lund, Sweden, 2019.

18. Foidl, H.; Felderer, M. Research Challenges of Industry 4.0 for Quality Management. In Innovations in Enterprise Information Systems Management and Engineering. ERP Future 2015; Felderer, M., Piazolo, F., Ortner, W., Brehm, L., Hof, H.-J., Eds.; Lecture Notes in Business Information Processing; Springer: Cham, Switzerland, 2016; Volume 245.

19. Lages, L.F. VCW-Value Creation Wheel: Innovation, technology, business, and society. J. Bus. Res. 2016, 69, 4849-4855. [CrossRef]

20. Aulbur, W.; Arvind, C.J.; Bigghe, R. Skill Development for Industry 4.0. WHITEPAPER-BRICS Skill Development Working Group-FICCI, Roland Berger GMBH. 2016. Available online: http:www.globalskillsummit.com/Whitepaper-Summary.pdf (accessed on 15 December 2020).

21. Meissner, H.; Ilsen, R.; Aurich, J.C. Analysis of Control Architectures in the Context of Industry 4.0. Procedia CIRP 2017, 62, 165-169. [CrossRef]

22. Barreto, L.; Amaral, A.; Pereira, T. Industry 4.0 implications in logistics: An overview. Procedia Manuf. 2017, 13, 1245-1252. [CrossRef]

23. Lucke, D.; Constantinescu, C.; Westkämper, E. Smart Factory-A Step towards the Next Generation of Manufacturing. In Manufacturing Systems and Technologies for the New Frontier; Springer: London, UK, 2008; pp. 115-118. [CrossRef]

24. Benešová, A.; Tupa, J. Requirements for education and qualification of people in Industry 4.0. Procedia Manuf. 2017, 11, 2195-2202. [CrossRef]

25. Juran.com. Quality 4.0: The Future of Quality? Available online: https://www.juran.com/blog/quality-4-0-the-future-ofquality / (accessed on 17 June 2020).

26. Carvalho, A.V.; Enrique, D.V.; Chouchene, A.; Charrua-Santos, F. Quality 4.0: An Overview. Procedia Comput. Sci. 2021, 181, 341-346. [CrossRef]

27. Forero, R.S.D.V. Quality 4.0-How to Handle Quality in the Industry 4.0 Revolution. Master's Thesis, Chalmers University of Technology, Gothenburg, Sweden, 2020.

28. Alcácer, V.; Cruz-Machado, V. Scanning the Industry 4.0: A Literature Review on Technologies for Manufacturing Systems. Eng. Sci. Technol. Int. J. 2019, 22, 899-919. [CrossRef]

29. Samans, R.; Davis, N. Advancing Human-Centred Economic Progress in the Fourth Industrial Revolution. A Leadership Agenda for G20 Governments. World Economic Forum. 2017. Available online: https:/ / www.g20-insights.org/ (accessed on 17 June 2020).

30. Thomson, S. 13 Signs the Fourth Industrial Revolution is Almost Here. World Economic Forum. 2018. Available online: https: / / www.weforum.org/agenda/2015/09/13-signs-the-fourth-industrial-revolution-is-almost-here/ (accessed on 18 June 2020).

31. Nikolova-Jahn, I. Quality Management and Requirements of the Fourth Technical Revolution. Int. Sci. J. Ind. 4.0 2019, 4, 61-63.

32. Gunasekaran, A.; Subramanian, N. Quality management in the 21st century enterprises: Research pathway towards Industry. 4.0 Int. J. Prod. Econ. 2019, 207, 125-129. [CrossRef]

33. Araújo, R.; Santos, G.; da Costa, J.B.; Sá, J.C. The quality management system as a driver of organizational culture: An empirical study in the Portuguese textile industry. Qual. Innov. Prosper. 2019, 23, 1-24. [CrossRef]

34. Bravi, L.; Murmura, F.; Santos, G. The ISO 9001:2015 quality management system standard: Companies' drivers, benefits and barriers to its implementation. Qual. Innov. Prosper. 2019, 23, 64-82. [CrossRef]

35. Santos, G.; Murmura, F.; Bravi, L. Developing a model of vendor rating to manage quality in the supply chain. Int. J. Qual. Serv. Sci. 2019, 11, 34-52. [CrossRef] 
36. Sá, J.C.; Amaral, A.; Barreto, L.; Carvalho, F.; Santos, G. Perception of the importance to implement ISO 9001 in organizations related to people linked to quality-an empirical study. Int. J. Qual. Res. 2019, 13, 1055-1070. [CrossRef]

37. Santos, G.; Gomes, S.; Braga, V.; Braga, A.; Lima, V.; Teixeira, P.; Sá, J.C. Value creation through quality and innovation-A case study on Portugal. TQM J. 2019, 31, 928-947. [CrossRef]

38. Félix, M.J.; Silva, S.; Santos, G.; Doiro, M.; Sá, J.C. Integrated product and processes development in design: A case study. Procedia Manuf. 2019, 41, 296-303. [CrossRef]

39. Brown, A. Quality: Where have we come from and what can we expect? TQM J. 2013, 25, 585-596. [CrossRef]

40. WEF (World Economic Forum). Future of Jobs Survey. Available online: http:/ /www3.weforum.org/docs/WEF_Future_of_ Jobs_2018.pdf (accessed on 18 June 2020).

41. Santos, G.; Bravi, L.; Murmura, F. Attitudes and behaviours of Italian 3D prosumer in the Era of Additive Manufacturing. Procedia Manuf. 2017, 13, 980-986.

42. Bravi, L.; Murmura, F.; Santos, G. Manufacturing labs: Where new digital technologies help improve life quality. Int. J. Qual. Res. 2018, 12, 957-974.

43. Santos, G.; Murmura, F.; Bravi, L. Fabrication laboratories: The development of new business models with new digital technologies. J. Manuf. Technol. Manag. 2018, 29, 1332-1357. [CrossRef]

44. Félix, M.J.; Gonçalves, S.; Jimenez, G.; Santos, G. The contribution of design to the development of products and manufacturing processes in the Portuguese industry. Procedia Manuf. 2019, 41, 1055-1062. [CrossRef]

45. Murmura, F.; Bravi, L.; Santos, G. Sustainable process and product innovation in the eyewear sector: The role of industry 4.0 enabling technologies. Sustainability 2021, 13, 365. [CrossRef]

46. Santos, G.; Rebelo, M.; Barros, S.; Silva, R.; Pereira, M.; Ramos, G.; Lopes, N. Developments regarding the integration of the occupational safety and health with quality and environment management systems. In Occupational Safety and Health-Public Health in the 21st Century; Kavouras, I., Chalbot, M.G., Eds.; The Nova Science Publishers: New York, NY, USA, 2014; Chapter 6; pp. 113-146. ISBN 978-1-63117-698-2.

47. Doiro, M.; Fernández, F.J.; Félix, M.J.; Santos, G. Machining operations for components in kitchen furniture: A comparison between two management systems. Procedia Manuf. 2019, 41, 10-17. [CrossRef]

48. Ribeiro, P.; Sá, J.C.; Ferreira, L.P.; Silva, F.J.G.; Pereira, M.T.; Santos, G. The impact of the application of lean tools for improvement of process in a plastic company: A case study. Procedia Manuf. 2019, 38, 765-775. [CrossRef]

49. Rodrigues, J.; de Sá, J.C.V.; Ferreira, L.P.; Silva, F.J.G.; Santos, G. Lean management "quick-wins": Results of implementation. A case study. Qual. Innov. Prosper. 2019, 23, 3-21. [CrossRef]

50. Azevedo, J.; Sá, J.C.; Ferreira, L.P.; Santos, G.; Cruz, F.M.; Jimenez, G.; Silva, F.J.G. Improvement of production line in the automotive industry through lean philosophy. Procedia Manuf. 2019, 41, 1023-1030. [CrossRef]

51. Santos, G.; Mandado, E.; Silva, R.; Doiro, M. Engineering learning objectives and computer assisted tools. Eur. J. Eng. Educ. 2019, 44, 616-628. [CrossRef]

52. Carvalho, F.; Santos, G.; Gonçalves, J. Critical analysis of information about integrated management systems and environmental policy on the Portuguese firms' website, towards sustainable development. Corp. Soc. Responsib. Environ. Manag. 2020, 27, 1069-1088. [CrossRef]

53. Bravi, L.; Santos, G.; Pagano, A.; Murmura, F. Environmental management system according to ISO 14001:2015 as a driver to sustainable development. Corp. Soc. Responsib. Environ. Manag. 2020, 27, 2599-2614. [CrossRef]

54. Talapatra, S.; Santos, G.; Uddin, K.; Carvalho, F. Main benefits of integrated management systems through literature review. Int. J. Qual. Res. 2019, 13, 1037-1054. [CrossRef]

55. Bravi, L.; Murmura, F.; Santos, G. Additive Manufacturing: Possible Problems with Indoor Air Quality. Procedia Manuf. 2019, 41, 952-959. [CrossRef]

56. Costa, A.R.; Barbosa, C.; Santos, G.; Rui Alves, M. Six sigma: Main metrics and $\mathrm{r}$ based software for training purposes and practical industrial quality control. Qual. Innov. Prosper. 2019, 23, 83-100. [CrossRef]

57. Barbosa, L.C.F.M.; de Oliveira, O.J.; Santos, G. Proposition for the alignment of the integrated management system (quality, environmental and safety) with the business strategy. Int. J. Qual. Res. 2018, 12, 925-940.

58. Santos, G.; Sá, J.C.; Oliveira, J.; Ramos, D.G.; Ferreira, C. Quality and safety continuous improvement through lean tools. In Lean Manufacturing-Implementation, Opportunities and Challenges; Silva, F., Ferreira, L., Eds.; Nova Science Publishers: New York, NY, USA, 2019; pp. 165-188.

59. Xu, L.; Peng, X.; Pavur, R.; Prybutok, V. Quality management theory development via meta-analysis. Int. J. Prod. Econ. 2020, 229, 107759. [CrossRef]

60. Turisova, R.; Sinay, J.; Pacaiova, H.; Kotianova, Z.; Glatz, J. Application of the EFQM Model to Assess the Readiness and Sustainability of the Implementation of I4.0 in Slovakian Companies. Sustainability 2020, 12, 5591. [CrossRef]

61. Coelho, F.; Augusto, M.; Lages, L.F. Contextual factors and the creativity of frontline employees: The mediating effects of role stress and intrinsic motivation. J. Retail. 2011, 87, 31-45. [CrossRef]

62. Fundin, A.; Backström, T.; Johansson, P.E. Exploring the emergent quality management paradigm. Total Qual. Manag. Bus. Excell. 2019, 32, 476-488. [CrossRef]

63. Chand, K.P.; Kumar, A.S.; Mittal, A. Emotional intelligence and its relationship to employability skills and employer satisfaction with fresh engineering graduates. Int. J. Qual. Res. 2019, 13, 735-752. [CrossRef] 
64. Milano, M. The Digital Skills Gap Is Widening Fast. Here's How to Bridge It. 2019. Available online: https:/ /www.weforum.org/ agenda/2019/03/the-digital-skills-gap-is-widening-fast-heres-how-to-bridge-it/ (accessed on 8 July 2020).

65. PwC. Workforce of the Future. The Competing Forces Shaping 2030. 2017. Available online: www.pwc.com/people (accessed on 15 December 2020).

66. Bakhshi, H.; Downing, J.M.; Osborne, M.A.; Schneider, P. The Future of Skills Employment in 2030; Pearson: London, UK; Nesta: London, UK, 2017.

67. Kothari, C.R. Research Methodology, Methods and Techniques, 2nd ed.; New Age International (P) Limited: New Delhi, India, 2011; pp. 109-110.

68. Michener, W.K. Quantitatively Evaluating Restoration Experiments: Research Design, Statistical Analysis, and Data Management Considerations. Restor. Ecol. 1997, 5, 324-337. [CrossRef]

69. Duran, C.; Çetindere, A.; Şahan, Ö. An Analysis on the Relationship Between Total Quality Management Practices and Knowledge Management: The Case of Eskişehir. Procedia Soc. Behav. Sci. 2014, 109, 65-77. [CrossRef]

70. Simon, S.K.L. Quality management and job satisfaction: An empirical study. Int. J. Qual. Reliab. Manag. 1995, 12, 72-78. [CrossRef]

71. Tortora, A.M.R.; Maria, A.; Valentina, D.P.; Iannone, R.; Cesare Pianese, C. A survey study on Industry 4.0 readiness level of Italian small and medium enterprises. Procedia Comput. Sci. 2021, 180, 744-753. [CrossRef]

72. Chengula, Z.; Morato, M.A.R.; Thurner, T.; Wiedensohler, Y.; Martin, L. State of Industry 4.0 across six French companies: A pilot study. In Proceedings of the IEEE International Conference on Engineering, Technology and Innovation (ICE/ITMC), Stuttgart, Germany, 17-20 June 2018.

73. Kuhn, M.; Schaefer, F.; Otten, H. Process complexity as a future challenge-A quality management perspective. TQM J. 2018, 30, 701-716. [CrossRef]

74. Antony, J. What does the future hold for quality professionals in organizations of the twenty-first century? TQM J. 2013, 25, 677-685. [CrossRef]

75. Shin, W.S.; Dahlgaard, J.J.; Dahlgaard-Parkc, S.M.; Kima, M.G. A Quality Scorecard for the era of Industry 4.0. Total Qual. Manag. 2018, 29, 959-976. [CrossRef]

76. Popkova, E.G. Quality of Digital Product: Theory and Practice. Int. J. Qual. Res. 2019, 14, 201-218. [CrossRef]

77. Shokhnekh, A.V. The main notions, principles, and procedures of strategic quality management of small business in the system of digital economy in view of risks of drift: A cognitive approach. Int. J. Qual. Res. 2019, 13, 655-668. [CrossRef]

78. Gritsuk, N.V.; Gamulinskaya, N.V.; Petrova, E.V. The innovative approach to managing the product quality in the digital economy: Intellectual accounting and audit. Int. J. Qual. Res. 2020, 14, 543-558. [CrossRef]

79. Zaidin, N.H.M.; Diah, M.N.M.; Po, H.Y.; Sorooshian, S. Quality Management in Industry 4.0 Era. J. Manag. Sci. 2018, 8, 82-91. [CrossRef]

80. Ghobakhloo, M. The future of manufacturing industry: A strategic roadmap toward Industry 4.0. J. Manuf. Technol. Manag. 2018, 29, 910-936. [CrossRef]

81. Nenadál, J. The New EFQM Model: What is Really New and Could Be Considered as a Suitable Tool with Respect to Quality 4.0 Concept? Qual. Innov. Prosper. 2020, 24, 17-27. [CrossRef]

82. Sung, T.K. Industry 4.0: A Korea perspective. Technol. Forecast. Soc. Chang. 2018, 132, 40-45. [CrossRef]

83. Fonseca, L.; Amaral, A.; José Oliveira, J. Quality 4.0: The EFQM 2020 Model and Industry 4.0 Relationships and Implications. Sustainability 2021, 13, 3107. [CrossRef]

84. Liao, Y.; Deschamps, F.; Loures, E.F.; Ramos, L.F.P. Past, present and future of Industry 4.0-a systematic literature review and research agenda proposal. Int. J. Prod. Res. 2017, 55, 3609-3629. [CrossRef]

85. Miller, K. Smart Quality Management: The Impact of Industry 4.0 on QMS 2020. Available online: https:/ /www.pilgrimquality. $\mathrm{com} / \mathrm{blog}$ / smart-quality-management-impact-industry/ (accessed on 7 July 2020).

86. Murugiah, T.K. Challenges in Transforming Assessments for 21st Century Skills Development: Lecturers' Perspective. Asian J. Educ. Train. 2020, 6, 41-46. [CrossRef]

87. Blanchet, M.; Rinn, T.; Von Thaden, G.; Thieully, G. Industry 4.0: The New Industrial Revolution-How Europe Will Succeed; Roland Berger Strategy Consultants: Munich, Germany, 2014.

88. Cotet, G.B.; Balgiu, B.A.; Zaleschi, V.C. Assessment procedure for the soft skills requested by Industry 4.0. MATEC Web Conf. 2017, 121, 07005. [CrossRef]

89. Maisiri, W.; Darwish, H.; van Dyk, L. An investigation of Industry 4.0 skills requirements. S. Afr. J. Ind. Eng. 2019, 30, 90-105. [CrossRef]

90. Zgodavova, K.; Hudec, O.; Palfy, P. Culture of quality: Insight into foreign organizations in Slovakia. Total Qual. Manag. Bus. Excell. 2017, 28, 1054-1075. [CrossRef]

91. Park, S.H.; Shin, W.S.; Park, Y.H.; Lee, Y. Building a new culture for quality management in the era of the Fourth Industrial Revolution. Total Qual. Manag. 2017, 28, 934-945. [CrossRef]

92. Santos, G.; Afonseca, J.; Lopes, N.; Félix, M.J.; Murmura, F. Critical success factors in the management of ideas as an essential component of innovation and business excellence. Int. J. Qual. Serv. Sci. 2018, 10, 214-232. [CrossRef]

93. Mohelska, H.; Sokolova, M. Management Approaches for Industry 4.0-The organizational culture perspective. Technol. Econ. Dev. Econ. 2018, 24, 2225-2240. [CrossRef] 
94. Stentoft, J.; Jensen, K.W.; Philipsen, K.; Haug, A. Drivers and barriers for Industry 4.0 readiness and practice: A SME perspective with empirical evidence. In Proceedings of the 52nd Hawaii International Conference on System Sciences, Wailea, HI, USA, 8-11 January 2019; pp. 5155-5164.

95. Walendowski, J.; Kroll, H.; Schnabl, E. Regional Innovation Monitor Plus 2016: Thematic Paper 3-Industry 4.0, Advanced Materials (Nanotechnology); European Communities: Brussels, Belgium, 2016.

96. Ingaldi, M.; Ulewicz, R. Problems with the Implementation of Industry 4.0 in Enterprises from the SME Sector. Sustainability 2020, 12, 217. [CrossRef]

97. Osmonbekov, T.; Johnston, W.J. Adoption of the internet of things technologies in business procurement: Impact on organizational buying behaviour. J. Bus. Ind. Mark. 2018, 33, 781-791. [CrossRef]

98. Rüßmann, M.; Lorenz, M.; Gerbert, P.; Waldner, M.; Justus, J.; Engel, P.; Harnisch, M. Industry 4.0: The future of productivity and growth in manufacturing industries. Boston Consult. Group 2015, 9, 54-89.

99. Lee, J.; Bagheri, B.; Kao, H.A. A cyber-physical systems architecture for industry 4.0-based manufacturing systems. Manuf. Lett. 2015, 3, 18-23. [CrossRef]

100. Gottge, S.; Menzel, T.; Forslund, H. Industry 4.0 technologies in the purchasing process. Ind. Manag. Data Syst. 2020, 120, 730-748. [CrossRef]

101. Dalenogare, L.S.; Benitez, G.B.; Ayala, N.F.; Frank, A.G. The expected contribution of Industry 4.0 technologies for industrial performance. Int. J. Prod. Econ. 2018, 204, 383-394. [CrossRef]

102. Ojra, A. Revisiting Industry 4.0: A new definition. In Proceedings of the Science and Information Conference, London, UK, 10-12 July 2018; Springer: Cham, Switzerland, 2018; pp. 1156-1162.

103. Tsukahara, T. Commentary: New Currents in Science: The Challenge of Quality, examining the discrepancies and incongruities between Japanese techno-scientific policy and the citizens' science movement in post-3/11 Japan. Futures 2017, 91, 84-89. [CrossRef] 